\title{
Research on Strategic Operation of Architectural Engineering's Project Progress
}

\author{
Chenhua Cui \\ School of architecture, Xianyang Vocational Technical College, No 1 tongyi Road, Fengwei New \\ District, Xianyang City, Shaanxi Province, China.
}

1449202824@qq.com

Keywords: Architectural; Progress; Operate; Engineering's project; Engineering department(ED)

\begin{abstract}
Because the progresses operation of the architectural engineering's project is an organic part of the architectural engineering 's project management and cooperated-building parties work, its operation quality is influential to the progress of architectural engineering's project, And indirectly to the cost and quality management of the architectural engineering's project. So in this study, Positive and highly concern about the problem of "how to operate the progress of the architectural engineering's project ", and target to carry out related work, strive to achieve the smooth and efficient operation of each architectural engineering's project. In a systematic, dynamic and comprehensive method operate the progress of the architectural engineering's project Obtain effectively and best strategic system on operating progress of the architectural engineering's project From this study, it is found that the importance of the progress plan and the status of the operating progress is very high and cannot be underestimated.
\end{abstract}

\section{Introduction}

Operating the progress of the architectural engineering's project is of great significance to the management of architectural engineering's project and the construction industry. Operating the progress and controlling the quality, the cost of architectural engineering's project are closely linked and causal relationship, only better coordinating the relationship between the three, we can ensure the orderly operation of the whole project, and construction parties can achieve their own objectives and obtain the benefit. So under the optimal premise of the construction enterprises ensuring the engineering's quality and cost control, scientifically and rationally operate construction progress, ensure that the amount of the project is completed as scheduled, let the construction enterprise realize own economic efficiency smoothly. [1] The construction progress of the architectural engineering's project is designed after investigating and arguing the feasibility of the whole project. In the design phase, according to the actual situation of the construction site and the needs of the time limit for a project, reasonably formulate progress plan. The construction progress needs to follow certain scientific nature and the regularity, neither can blindly aggressive nor can be delayed. Blind rash will break the original rules, upset existing operation process; the quality of the project will be affected. And delaying the progress will increase the cost of construction and reduce the economic interests of the construction enterprise. Therefore, the control of the construction progress should have the scientific nature. Reasonably according to plans execution, only then can guarantee the project to finish smoothly. [2] 


\section{Analysis of the Factors Associated with the Progress of the Architectural Engineering's Project}

Table 1 Operating procedure of engineering's progress (step list)

\begin{tabular}{|c|c|c|c|}
\hline step & specific content and task & $\begin{array}{l}\text { responsible } \\
\text { person or } \\
\text { department }\end{array}$ & output \\
\hline $\begin{array}{l}\text { ED passing the } \\
\text { construction } \\
\text { schedule to the } \\
\text { owner }\end{array}$ & $\begin{array}{l}\text { ED pass the construction schedule of the owner to construction } \\
\text { uint,and instruct the construction unit to develop a detailed } \\
\text { implementation plan, should include the plan of year close next } \\
\text { month and week }\end{array}$ & $\begin{array}{l}\text { ED、 } \\
\text { construction } \\
\text { unit }\end{array}$ & $\begin{array}{l}\text { constructions } \\
\text { progress plan of } \\
\text { construction unit }\end{array}$ \\
\hline $\begin{array}{l}\text { compiling total、 } \\
\text { monthly progress } \\
\text { plan }\end{array}$ & $\begin{array}{l}\text { ED instruct the construction units to formulate the detailed plan of } \\
\text { year close next month and week according to the requirements of } \\
\text { the owner before the specified date, and submit to the owner and } \\
\text { supervisor for approval }\end{array}$ & $\begin{array}{l}\text { ED、 } \\
\text { construction } \\
\text { unit }\end{array}$ & $\begin{array}{l}\text { annual constructions } \\
\text { plan and close next } \\
\text { month constructions } \\
\text { plan }\end{array}$ \\
\hline reviewing plan & $\begin{array}{l}\text { ED、 supervisor review the construction organization and schedule of } \\
\text { the construction unit, joint 、 audit 、 amendment 、 approval }\end{array}$ & ED、 supervisor & $\begin{array}{l}\text { review and reply of } \\
\text { constructions plan }\end{array}$ \\
\hline $\begin{array}{l}\text { recording and } \\
\text { issuing }\end{array}$ & $\begin{array}{l}\text { For the approval of the progress of the project plan to amend the } \\
\text { written, record in the department, distribute to construction unit } \\
\text { and performed by the construction unit }\end{array}$ & ED & $\begin{array}{c}\text { official draft of } \\
\text { constructions plan }\end{array}$ \\
\hline $\begin{array}{l}\text { organizing and } \\
\text { implementing }\end{array}$ & $\begin{array}{l}\text { construction units should be strictly implemented according to the } \\
\text { approved plan, owners site engineering through site inspection, } \\
\text { supervision to control progresses implementation of construction } \\
\text { unit from time to time, record inspection diary everyday , find } \\
\text { problems in time to solve or report to the superior, the site } \\
\text { supervision engineer of supervision unit through the inspection of the } \\
\text { site, to carry out supervision and control the progresses } \\
\text { implementation of the construction unit find problems in time to } \\
\text { solve or report to the superior, involved in the coordination of each } \\
\text { department, led by the ED in accordance with the relevant provisions } \\
\text { timely to complete the coordination[3] }\end{array}$ & $\begin{array}{l}\text { construction } \\
\text { unit、ED、 } \\
\text { supervisor }\end{array}$ & $\begin{array}{c}\text { summary of the } \\
\text { implementation of } \\
\text { weekly and monthly } \\
\text { schedule }\end{array}$ \\
\hline summary report & $\begin{array}{c}\text { weekly monthly summarize written report on the implementation of } \\
\text { progress and send to the ED }\end{array}$ & $\begin{array}{l}\text { construction } \\
\text { unit、ED }\end{array}$ & $\begin{array}{l}\text { summary material of } \\
\text { progresses plan }\end{array}$ \\
\hline $\begin{array}{l}\text { summary } \\
\text { analysis } \\
\text { correction } \\
\text { adjustment }\end{array}$ & $\begin{array}{l}\text { ED according to the site situation and summary report of construction } \\
\text { unit analyze and find out the experience and lessons of constructions } \\
\text { management, according to the analysis results propose the adjustment } \\
\text { scheme and the constructions schedule of close next month }\end{array}$ & $\begin{array}{l}\text { construction } \\
\text { unit、ED }\end{array}$ & $\begin{array}{l}\text { result of summary } \\
\text { analysis of progress } \\
\text { plan, constructions } \\
\text { plan of close next } \\
\text { month }\end{array}$ \\
\hline $\begin{array}{l}\text { Executing } \\
\text { adjusted } \\
\text { schedule }\end{array}$ & $\begin{array}{l}\text { according to progresses plan adjusted issued by ED, strictly } \\
\text { implement }\end{array}$ & $\begin{array}{l}\text { construction } \\
\text { unit、ED }\end{array}$ & $\begin{array}{c}\text { adjusted } \\
\text { constructions } \\
\text { schedule }\end{array}$ \\
\hline
\end{tabular}

According to Table 1, we can find the following factors;

Human Factor. It mainly refers to the quality level of the personnel management of the project department, the qualification of construction personnel.

Construction Fund. In order to smoothly complete the construction of the project must have sufficient funds as a guarantee. Once the construction unit does not meet the funds of the basic construction need or fees are not in place, the purchase work related building materials will be stranded, the construction progress will be delayed, Increase the idle time of construction. The smooth construction of the project must have sufficient funds as a guarantee. [4]

Environmental Factor. Project construction especially the construction of outdoor project is highly dependent on the environment. Bad environment can even lead to serious failure of project management. The environmental factors that affect the project construction progress are the weather, the geological change, the bad climate. If the above happens, not only the duration is difficult to 
guarantee but also the continued construction is a problem.

Technical Factor. Technical factors include the formulation of the construction plan and the determination of the specific construction craft. The construction plan is chaotic or the construction craft does not conform to the concrete engineering practice. Which will pay more time for the project planning in the process of construction process of actual project, and delay the construction progress of the whole project. [5]

\section{The Strategy of Operating the Progress of Constructional Engineering Project}

Giving Full Play to the Important Role of Supervision in Construction Engineering. Supervision engineer as the hiring manager, should grasp the whole, and coordinate the relationship between the parties, constantly supervise and inspect the progress management of the construction unit, timely detect and correct problems, strive for the project is completed on schedule. For example the design stage must be tightly grasp so as to avoid time limits delay caused by excessive design correction; the fund preparation must be sufficient, simultaneously for speeding up the progress to set up the reward and so on.

Enhancing Track Inspection. The authorized progress plan is basis of the project implementation and coordination, according to the authority and time requirements of the schedule review manager should timely review the progress plan. Review should pay attention to the time and spaces arrangement on the operation of each process whether it is reasonable or not, whether the resource plan of person, material. Machine and construction intensity of engineering quantity satisfy requests or not, and according to the actual situation to determine the feasibility of progress plan. During the construction manager adopt the partition inspection for the examination and approval of detailed process plan according to the specific situations. [6]

Determining Reasonable Time Limit Conforms to the Objective and Practical. The engineer must carry on the accurate time limits calculation to the projects progress goal for effective control and management of projects construction progress. Scientifically analyze and measure the scale of the construction of the project, project quantity, complexity, duration, fund possibility of implementation, climatic and geological conditions, then calculate the best time limit for a project. In order to successfully complete control and management of the construction progress, the engineer should also pay attention to following four aspects firstly, construction party's construction organization design should be practical, each construction plan should be specific, to develop practical measures to cope with the construction; secondly, examine and approve each procedure in accordance with the requirements of the standard, the general objectives and plans of the progress of the project shall be in accordance with the local conditions; thirdly, in the process of construction progress control, the actual progress should be compared with the planned progress, once appears deviation, should timely analyze the reason, formulate corrective measures and implemented; fourthly, all sorts of unit involved in the project construction should coordinate with each other for engineering's progress, enable each unit all to be possible to achieve consistently in the progress, coordinate and implement management of the project progress with the best organization. [7]

\section{Attaching Great Importance to Establishment on the Construction Progress Plan and Dynamic Control.}

Establishment and Review on Progress Plan of Architectural engineering's Project

Establishment Plan of Projects Progress. The content of establishment plan of project progress mainly has progress plan and progress control work plan. The main goal of establishing plan is to ensure that the construction task is completed in accordance with the time limit. The main purpose of the progress control work plan is to guide the management personnel to implement the progress plan, its foundation of establishment is overall deployment of the progress plan, progress control work plan in construction stage is the deepening of the work plan, the project construction control division is generally responsible for the establishment of this kind of work plan, it is the guarantee of implementation progress plan. 
Review of Progress's Plan

At present, most of the construction enterprises pay attention to cost and quality control, respectively there is a mechanism of examination and review to the construction cost and quality, but not for the progress plan. The reasons for reviewing progress plan are mainly in the following aspects firstly, establishment strengths level of business is limited, the progress plan has not been considered comprehensively. Secondly, progress plan involves the problem of balance between different majors and engineering subsystems. Engineering's progress plan needs in detail to be reviewed by the company's management after the completion of the establishment, so existing problems can be found out and solved, to ensure the smooth progress of construction. [8]

Operating Process of Project Implementation and Dynamic Assessment. According to Progress's Plan to Strengthen the Control of Progress in the Construction Stage

The work is vital work of progress management, the main purpose is to perfectly perform each dynamic control and coordinate the relationship between the units. Carry on the decomposition and refinement of the progress plan of controllability, in order to achieve the dynamic controlling engineering progress, review the construction progress plan of subcontractors. In the process of tracking and inspecting the execution of the progress plan, for the problems which have appeared needs to take corresponding measures to solve them. Site management personnel should successfully complete the following work: firstly, the situation of the personnel taking place. Site management personnel first in place to ensure that there are enough workers to work, and need to compile a reasonable labor plan. Secondly, complete the preparatory workof the material for each process, and need to complete various quality examination as well as the sample work. According to the demand of the engineering's progress plan, the material purchase plan needs scientific and reasonable. Thirdly, when equipped with machinery site management personnel need to satisfy the economical rationality. Especially the tower crane and other machinery of more great impact on engineering, its basis to the final lifting are required to carry out a rigorous review. Project also should choose the template reasonably according to own situation. Fourthly, construction units need to develop detailed construction plan of rainy season and winter, in order to ensure the orderly conduct of the project. Fifthly, adopting advanced and reasonable construction technology measures, compiling construction scheme and technical clarification in a targeted manner, using advanced construction equipment at the same time, which are effectively measures of guaranteeing construction progress. Sixthly, organizing streamlined work, shortening the duration of the procedure in order to ensure the construction progress. Need to strictly carry on the control of key circuit of the construction. There are often many remedial treatments to the problem of the non-essential line; however, delayed working procedure on the key line is needed to compensate by working overtime. So in the process of construction, need reasonable allocation of resources to ensure normal construction of the critical paths working procedure. The main reason of occurring deviation between the actual construction progress and the planned progress is out of place on implementation of construction progress control、 existing a series of problems in the construction progress , changes in the construction progress caused by changes in the project. In view of these reasons, we need to take different measures to achieve the requirements of progress management. [9]

\section{Rectification}

In the process of projects construction, affected by the external factors, the constructions project will appear that the engineering's progress does not match the plan. At this time need the administrative personnel to carry on the inspection and analysis to the progress plan, find out the deviation between the actual progress and the progress and analyze the reasons. If it is the cause of the construction, it is required to take measures to correct the deviation to ensure the completion of the project on schedule. Rectification is an important measure to guarantee the time limit, the premise of correcting the deviation is to find out the declinational reason of the time limit for a project. So the constructions management personnel need to have a keen insight. [10] 
Designing Department's Measure. In order to fulfill the design contract, timely submit the design document of constructions drawing, the design unit shall take effective measures to control the designs progress of the construction project: Through own plan department, is responsible for the design units establishment of annual plan and the engineering's project design progress plan. Establish and perfect the technical and economic quota of design, carry on establishment and evaluation of plan according to quotas requirements. To implement the technical and economic responsibility system of the design work, and to link the economic benefits of the employees to the quantity and quality of their tasks. Establishes the practical and feasible design total progress plan, the gradual design progress plan and the design progress work plan. In the preparation of the plan, to strengthen cooperation with the owners supervision units research institutes and contractors, so that the design schedule is active and reliable. Seriously implement the design schedule, strive to make the design work of the rhythm, orderly, reasonable lap. In the implementation of the plan, to regularly check the implementation of the plan, and timely to adjust the design progress, so that the design work is always in a state of control. Adhere to the basic construction procedures, as far as possible to avoid the "three simultaneous" design of the "side design, preparation, while the construction". Constantly analyze and summarize the work experience of the design progress control, and gradually improve the level of design schedule control. [11]

\section{Conclusion}

The new adjustments measures and the constructions plan are produced, also need to review the measures and the plan and analyze the results of the adjustment measures, analyze the new time limit whether conform to the goals requirement. The operating progress of the architectural engineering runs through the whole process of the architectural engineering, effective operations ensure the safety of construction and timely completion of the architectural engineering, and provide the guarantee for realization of the construction enterprise economic benefit and social benefit. Therefore, we not only ensure the quality of construction projects, but also to a reasonable control of the progress of the project, arrange the construction schedule, in order to complete the construction tasks of high quality and efficiency. Construction enterprise needs to place the progress management with in the cost, the quality same position. Then proceed with the preparation and evaluation of the project schedule, control the implementation of the project and dynamic evaluation. And after the completion of the project needs to carry on the classification catalog to the project progress material, give timely control and evaluation to the project schedule, guide the progress operation of the follow-up project.

\section{References}

[1] Sunna, the Tasks and Measures of Constructive Contractor's Schedule Control, J. Private Science and Technology. 2010(06).

[2] Xuehua, Shallowly Discusses on the Management and Control of Construction Quality and Progress of the Engineering Project, J. Shanxi Architecture. 2010(13).

[3] Chiqian, Shallowly Discusses on Effective Control Measures of Constructive engineering's Construction Schedule, J. Small and Medium-sized Enterprise Management and Science and Technology (the last ten-day of a month Publication) 2011(02).

[4] B. L. Zhao, Discussion on Construction Progress Control of Construction Project, J. Scientific and Technological Information. 2011(13).

[5] Y. G. Chen, Z. F. Jiang, Shallowly Discusses on Construction Progress Control of engineering's Project, J. Private Science and Technology. 2011 (03) : $118 \sim 119$. 
[6] J.S.Wen, Application of Basic Principle and Method of Dynamic Control in the Progress Management of Metallurgical Technological Transformation Project, J. Construction Economy.2011 (12).

[7] W.B.Wang, Based on P3 Progress Management 's Research on SDX Electric Power Construction Project 1, D.North China Electric Power University.2013 (03).

[8] H.P.Lu, Shallowly Analysis on the Influence Factors of Construction Schedule and Control Measures in Constructive engineering's Project, J.Vision of Science and Technology.2014 (01).

[9] Y.N.LI, Study on Constructive Progress Control of Construction Projects, J. Science and Technology Information.2010 (14).

[10]G.Q.Liu, the Control and Management of the Construction Schedule of the Construction Project, J. Value Engineering.2010 (23).

[11]D.K.Ning, On Construction Quality and Schedule Management of Construction Project, J. Frontiers of Architectural Research. 2012(08). 